\title{
A NOTE ON ORTHOGRAPHY
}

I have used English spelling for all proper names. Place names are listed as they appear on the maps issued by the cartographic service of the Republic of Zaire. All words and phrases in African languages are spelled according to the conventional orthography of H. W. Beckett's Hand Book of KiLuba (Luba-Katanga). Only a few peculiarities need be noted. The letter $i$ changes to $y$ and $u$ changes to $w$ before vowels. I have used the letter $p$, as in $m u$ lopwe (sacral king), but it should be kept in mind that $p$ undergoes a sound shift to $h$ among the Luba living in the former heartland of the Empire. 